\title{
II. Hadis Lisansüstü Öğrenci Sempozyumu 19 Kasım 2020
}

\section{Ertuğrul Tülekoğlu (1)}

İstanbul Üniversitesi İlahiyat Fakültesi Hadis Anabilim Dalı tarafından ilk defa geçtiğimiz y1l gerçekleştirilen Hadis Lisansüstü Öğrenci Sempozyumunun ikincisi 19 Kasım 2020'de Dünyayı etkisi altına alan covid-19 salgını nedeniyle çevrimiçi platform üzerinden gerçekleştirilmiştir. Her oturumunda yüksek katılım ile araştırmacıların dikkatini çeken sempozyumda ülkemizin çeşitli şehirlerinden 10 araştırmacı tebliğlerini dört oturumda sunmuştur.

Sempozyumun açı1ış oturumunda konuşan İstanbul İlahiyat Fakültesi Dekanı Prof. Dr. Ramazan Muslu, sempozyumun araştırmacılar için çalışmalarını paylaşma imkânı sağlaması ve İstanbul Üniversitesi'nin araştırma üniversitesi kimliğine katk1 sunmasına dikkat çekmiştir. Aynı oturumda Muslu'nun ardından konuşan Hadis Anabilim Dalı ve Sempozyum Düzenleme Kurulu Başkanı Prof. Dr. Mustafa Ertürk, eldeki imkanları azami düzeyde kullanılarak ve bu programların geliştirilerek devam ettirileceği mesajını vermiştir.

Çukurova Üniversitesi İlahiyat Fakültesi Dekanı Prof. Dr. Ali Osman Ateş’in başkanlık yaptığı birinci oturumda iki tebliğ sunulmuştur. Oturum, Eymen Kamer’in "Akran Râvi Tenkidinin Değeri” başlıklı tebliği sunumu ile başlamıştır. Kamer, fikhî ve itikâdî anlayışların teşekkülü esnasında yaşanan bazı münakaşaların ravi tenkidine etkisine ve bu doğrultuda akranların sert tutumlarına birkaç örnek üzerinden değinmiştir. Tebliğde bazı akran râvi cerhlerinin değeri ve bu tenkitlerin cerh ta'dîl ilminin güvenilirliğine olan etkisi tartışılmıştır. Tebliğin müzakeresini yapan Doç. Dr. Halil İbrahim Turhan, çalışmada akran ravi cerhi tanımının gerekliliğine, araştırmada kaynak kullanımının artırılmasına ve geç dönem müelliflerinin cerh tadil kitaplarında yer verdiği bazı iktibasların kontrol edilmesinin önemine dikkat çekmiştir.

\footnotetext{
* Sorumlu Yazar: Ertuğrul Tülekoğlu (Arş. Gör.), İstanbul Üniversitesi, illahiyat Fakültesi, Hadis Anabilim Dalı, İstanbul, Türkiye. E-posta: etulekoglu@istanbul.edu.tr ORCID: 0000-0003-1988-2405 
Birinci oturumun "el-Hucce alâ ehli'l-Medine ve İhtilafu Mâlik ve'ş-Şafii Adlı Eserler Çerçevesinde Şeybânî-Şafii İlişkisi”" adlı ikinci tebliğini sunan Ramazan Doğanay, Malik b. Enes (ö. 179/795), Muhammed eş-Şeybânî (ö. 189 /805) ve Şâfiî (ö. 204 /820) özelinde Hicri II. asırdaki bazı usul tartışmalarına değinmiş̧ir. Leys b. Sa'd (ö. 175/791), Şeybânî ve Şâfiî’nin Mâlik b. Enes'in Medine ameli ile sünnet tespitine yönelik tenkîdlerine değinen Doğanay, Şeybânî’nin Mâlik'i eleştirdiği el-Hucce alâ ehli 'l-Medîne ve Şâfiî̀nnin bu eleştirileri değerlendirmeye tabi tuttuğu er-Red 'alâ Muhammed b. el-Hasan eş-Şeybânî̀ sine vurgu yapmıştır. Doğanay, Şeybânî ve Şâfiî’nin Malik'i tenkid ettikleri hususlara bazı örnekler vermiştir. Tebliğin müzakeresi Prof. Dr. İshak Emin Aktepe tarafından yapılmıştır. Aktepe, tebliğ, makale gibi bilimsel araştırmalarda alan sınırlandırmasının önemini ve araştırmacının kendinden önce yapılmış çalışmalardan azami düzeyde faydalanmasının gerekliliğini vurgulamıştır. Aktepe, Şâfîi örneği üzerinden âlimlerin kanaatlerinin değişiklik gösterebileceğine de dikkat çekmiştir.

İkinci oturum Erciyes Üniversitesi İlahiyat Fakültesi Öğretim Üyesi Prof. Dr. Süleyman Doğanay başkanlığında yapılmıştır. Üç tebliğin sunulduğu oturumda ilk tebliğ sahibi Ayşe Boztaş, "Hadisler işığında bey 'u'l-garar” konusunu ele almıştır. Garar tanımı ve Hz. Peygamber'in yasakladığ 1 akitlere dair rivayetlere yer veren Boztaş, sened şeması, tenkide uğrayan raviler ve rivayetin hükmüne dair bilgi vermiştir. Tebliğ müzakeresini üstlenen Prof. Dr. Soner Duman, konunun önemine dikkat çekmiş ve metin tenkidinin gerekliliğini ifade etmiştir.

İkinci olarak Doç. Dr. Ayşe Esra Şahyar tarafindan müzakere edilen "Kadınların Namaz Kılma Şekilleri Üzerine Bir Değerlendirme" başlıklı tebliğ Zeynep Sena Yılmaz tarafından sunulmuştur. Yılmaz, konu hakkındaki rivayetlere ve fikhî mezheplerin buna dair görüşlerine değinmiştir. "Hz. Peygamber' in (sav) Öğretisinde Bulaşıcı Hastalıklar” adını taşıyan son tebliği sunan Musa Eşit, tıbb-ı nebevînin kaynağı hakkındaki tartışmaya ve 'bulaşıc1lık yoktur' hadisinin rivayet farklılıklarına değinmiştir. Prof. Dr. Veli Atmaca, tıbb-1 nebevînin tıp tarihi açısından önemine işaret ederek bu konularda yapılacak çalışmaların gerekliliğine işaret etmiştir.

Kocaeli Üniversitesi İlahiyat Fakültesi Öğretim Üyesi Prof. Dr. Yusuf Ziya Keskin başkanlığında yapılan üçüncü oturum Zehra İleri’nin, "İmanın Muhtevası Bağlamında Bir Mukayese- Buhârî’nin Sahîh'i ile Tirmizî’ nin Câmi “i Örnekliğinde” adlı tebliği ile başlamıştır. İleri'nin sunduğu tebliğin müzakeresini yapan Doç. Dr. Ömer Özpınar, tebliğin sonucunda ortaya koyulan -Buhârî’nin Sahih'ini yazarken amacının dönemdeki tartışmalara cevap vermekten çok sahih hadis nakli olduğu tespitinin temellendirilmesi gerektiğini vurgulamış, ayrıca akademik çalışmalarda şekil açısından yazım, üslup ve noktalama konularına dikkat edilmesi gerektiğini 
ifade etmiştir. Bu oturumun son konuşmacısı Ayşenur Gürtürk, "Buhari'nin Habeşistan'a Hicret Babındaki Hadislerin Değerlendirilmesi” başlıklı tebliği sunmuştur. Tebliği Dr. Öğr. Üyesi Mehmet Apaydın müzakere etmiştir. Gürtürk, Fethu'l-Bârî ve Umdetu'l Kârî şerhlerinde verilen bilgiler doğrultusunda Buhârî'nin Habeşistan'a hicret hakkında naklettiği hadislerin anlaşılmasına dikkat çekmiştir.

Sempozyumun son oturumu İstanbul Üniversitesi İlahiyat Fakültesi Öğretim Üyesi Prof. Dr. Hüseyin Hansu başkanlığında gerçekleştirilmiştir. İlk konuşmacı Lokman Korkut "Bâkıllanî’nin Hadis Yorumculuğu" başlıklı tebliği sunmuştur. Korkut, Bâkıllânî'nin (ö. 403/ 1013) et-Temhîd ve İntisâr adlı eserleri özelinde ayın yarılması, hurma kütüğünün inlemesi, yemeğin çoğalması mucizelerine ve Kur' an'ın cem'ine dair getirdiği yorumları konu edinmiştir. Tebliğ müzakeresini yapan Prof. Dr. Mehmet Said Toprak, çalışmada hadis yorumlarına gereği kadar değinilmediğini, Bâkıllânî'nin ifadelerinin daha iyi anlaşılması ve arka planının okunması gerektiğini vurgulamıştır. Doç. Dr. Abdurrahman Ece tarafından müzakeresi yapılan 'Ebû'lFeyz Ahmed el-Gumârî ve Hadisçiliği" başlıklı tebliği sunan Mehmet Sakar, sûfî kişiliği ile öne çıkan Gumarî’nin (ö. 1960) Mağrib’teki hadis çalışmaları arasındaki yerine, bazı hadisler hakkında sıhhat hükmü verme çabasına ve taklidi şiddetle reddetmesine dikkat çekmiştir. Oturumun ve Sempozyumun son tebliği Hüseyin Yürekli tarafından sunulan "Mukaddimetü İbni's-Salâh Adlı Esere Yöneltilen Eleştiriler ve Değerlendirilmesi”dir. Yürekli, Mukaddime’ye konu tertibi, sahih hadis tanımı, şaz, münker hadis tanımı, bazı hadis nevilerini eserine almaması gibi hususlarda yöneltilen tenkitlere değinmiştir. Tebliğin müzakeresi Prof. Dr. Hayri Kırbaşoğlu tarafindan yapılmıştır.

Sempozyum Prof. Dr. Hayri Kırbaşoğlu, Prof. Dr. Mustafa Ertürk, Prof. Dr. Süleyman Doğanay, Dr. Öğr. Üyesi Seyit Ali Güşen ve Dr. Öğr. Üyesi Nilüfer Kalkan Yorulmaz'ın kanaat ve değerlendirmelerini dile getirdiği kapanış oturumu ile sona ermiştir. Katılımcılar sempozyumun düzenli olarak devam ettirilmesi, Türkiye Hadisçiler Meclisinin tekrar başlatılması, araştırmacıların bu tür programlara katılması için teşvik edilmesi, sempozyumun önümüzdeki yıllarda hadis alanının bazı konuları temel alınarak ve uluslararası düzeyde gerçekleştirilmesi gibi tavsiyelerde bulunmuştur. 
